\title{
La proyección del concepto de la «hispanidad» en la actividad arquitectónica del primer franquismo
}

\author{
M. ${ }^{a}$ Isabel Cabrera García \\ Universidad de Granada \\ icabrera@ugr.es
}

RESUMEN: El régimen de Franco concedió un lugar relevante a la idea de la hispanidad, íntimamente ligada a su vocación imperial; idea que podía contribuir a fortalecer la identidad como país, y de cara hacia el exterior mantendría la ilusión de una proyección internacional que el régimen no tenía. En nuestro estudio nos aproximaremos a las fuentes históricas en las que se gesta la idea, a la reflexión teórica sobre la «hispanidad» en los primeros años del franquismo y a cómo se proyecta el mito en la arquitectura.

Tal concepto llevaría asociados un arsenal de lugares, fechas, celebraciones, imágenes..., con fuerte carga simbólica, que fueron haciéndose muy presentes en todas las manifestaciones culturales, y por tanto en el arte, popularizándose concepciones, imágenes y tópicos. Adquirían así un valor especial los principales edificios, conjuntos monumentales y ciudades vinculadas con el relato del descubrimiento del Nuevo Mundo: Granada, La Rábida, Guadalupe o Trujillo, poniendo de manifiesto la apropiación ideológica que del patrimonio histórico realizó el nuevo Estado.

PALABRAS CLAVE: Arquitectura; Arte; Hispanidad; Franquismo; Propaganda; Identidad nacional.

\section{The Projection of the Concept of «Hispanidad» on the Architectural Activity of the First Francoism}

ABSTRACT: Franco's regime gave a relevant place to the idea of «Hispanidad», a term related to the idea of Hispanicity, intimately linked to its imperial vocation. This idea could contribute to strengthen the identity as a country, and in an outward face would maintain the illusion of an international projection the regime did not have. In our study, we will approach the historical sources in which the idea developed, the theoretical reflection on «Hispanidad» (or Spanishness) in the early years of Franco's regime, and the way the myth is projected in architecture.

Such a concept would be associated with with numerous of places, dates, celebrations, images, etc. with a strong symbolic charge, which became very much part of all cultural manifestations, and therefore in art, popularizing conceptions, images, and clichés. Thus, the main buildings, monumental complexes, and cities linked to the story of the discovery of the New World acquired a special value: Granada, La Rábida, Guadalupe or Trujillo, demonstrating the ideological appropriation of the historical heritage by the new State.

KEYWORDS: Architecture; Art; Hispanidad; Francoism; Propaganda; National identity.

Tras la Guerra Civil, el régimen de Franco se apoyó en un potente discurso nacionalista que intentó superar las diferentes formas de entender la nación de todos los grupos que constituían el bando nacional, siendo el nacionalcatolicismo el ingrediente común aceptado por la mayoría. Este elemento nacionalista, que fue de capital importancia igualmente en el resto de los regímenes totalitarios europeos del periodo de entreguerras, iba a dejar una fuerte impronta en el plano estético y cultural. Discurso patriótico y retórica españolista que concedería protagonismo a un mito histórico-antropológico de gran valía para el Franquismo, el de la «hispanidad», vinculado íntimamente a las ideas de imperio, cruzada y catolicidad.

La «unidad de destino» a la que apelaba con insistencia el régimen, aludía directamente a su vocación imperialista, cuya justificación teórica presentó variantes entre las diferentes facciones que integraban el grupo de los vencedores. Aun-

Cómo citar este artículo: CABRERA GARCÍA, M. ${ }^{\text {a }}$ Isabel, «La proyección del concepto de la "hispanidad" en la actividad arquitectónica del primer franquismo", Boletín de Arte-UMA, n. ${ }^{\circ}$ 42, Departamento de Historia del Arte, Universidad de Málaga, 2021, pp. 23-40, ISSN: 0211-8483, e-ISSN: 2695-415X, DOI: http://dx.doi.org/10.24310/ BoLArte.2021.vi42.13047 
que todos coincidieron, convencidos, en que España poseía una esencia imperial y la historia vendría en su ayuda para avalar dicho convencimiento. Como explica el profesor Saz Campos: «Lo decía también la historia. España ya había sido Imperio y, por lo tanto, podía y debía volver a serlo, al modo en el que el Reich alemán era el tercero, y la Italia fascista, la cuarta Roma» (2003: 267). Apoyándose y retomando, entre otras, las ideas expuestas ya antes de la guerra por Menéndez Pidal (1935), muchos historiadores insistieron en que la configuración de la nacionalidad española y su vocación imperial tenía raíces profundas, era muy anterior a los siglos XVI y XVII (Tovar, 1941)'.

El comienzo de la Segunda Guerra Mundial y el avance de las potencias del Eje dieron impulso a las ideas imperiales, en especial a su concepción más combativa, la defendida por Falange, que aspiraba a «un Imperio real, material, hecho de poderío, fuerza y dominación» (Saz, 2003: 267) y contemplaba la idea de participar en la guerra y en un nuevo orden mundial surgido de ella obteniendo beneficios como los de recuperar Gibraltar o la expansión en África. También el nacionalismo imperial falangista iba a incluir Hispanoamérica en su discurso; la hispanidad por tanto sería indisociable de esa vocación imperialista, de la proyección universalista del nacionalismo español (Saz, 2003: 273).

El concepto de la hispanidad llevaría asociados un arsenal de lugares, fechas, celebraciones, imágenes..., con fuerte carga simbólica, que fueron haciéndose muy presentes en la literatura, el cine, la prensa, los programas de radio, los sellos postales o la publicidad, y como no podía ser de otra forma, en el arte, popularizándose concepciones, imágenes y tópicos. En nuestro estudio, sin olvidar las fuentes históricas decimonónicas en las que se gesta la idea -en torno a la celebración en 1892 del IV Centenario del Descubrimiento de América- y de las que se sirve el franquismo, nos aproximaremos a la reflexión teórica sobre la «hispanidad» en los primeros años del régimen y a cómo se proyecta el mito en la arquitectura.

El de hispanidad es un concepto poroso y versátil aunque no carezca de concreción. La idea en sí, y sobre todo el término que acabó designándola, es, como se sabe, relativamente reciente, remontándose a cosa de un siglo atrás. Su acuñación fue relativamente rápida, y en cierto modo extensión del desusado hispanidad como sinónimo de hispánico o propio de España ${ }^{2}$. En 1910, y escribiendo prefe- rentemente para lectores argentinos, lo empleaba Unamuno relacionándolo con neologismos como «americanidad», "argentinidad» e incluso italianitá que tenía por frecuente entonces (Unamuno, 1910). El concepto alcanzaría en todo caso, rápida propagación y, lo que sería más decisivo, decidida oficialización.

La idea nuclear cuenta con expresión muy anterior a la acuñación del término. A finales del siglo XIX, al atenuarse los resentimientos dejados por la Independencia y superada la inquina que pudieron suscitar las intervenciones españolas en Santo Domingo y Méjico y la Guerra del Pacífico a mediados de la centuria, las relaciones diplomáticas y consulares se hicieron fluidas, los intercambios económicos algo más importantes, aunque siempre reducidos, y los contactos humanos más amplios por el auge de la emigración española a varias de las nuevas repúblicas. En ese contexto, y con soberanía española aún plena en Cuba y Puerto Rico, además de en Filipinas, así como con la perspectiva de la conmemoración del IV Centenario del Descubrimiento, cuajaron iniciativas como la Unión Ibero-Americana. La Unión se configuró como una asociación dedicada a estrechar vínculos por medio del fomento de los intereses materiales de los países sudamericanos en su día posesión de la Corona española y su antigua metrópoli, sosteniendo la unidad de esos intereses y la comunidad de su cultura. No faltaba una vertiente propia de un grupo de interés y entre sus protectores figuraban accionistas del Banco Hispano Colonial. El fomento de relaciones comerciales y económicas en general lo asumió de forma más directa, no obstante, una publicación barcelonesa algo posterior, Mercurio. Revista comercial Hispano-Americana, orientada específicamente a extender el potencial que en tal orden de cosas representaban los vínculos trasatlánticos, partiendo de que, tras 1898, podían ser más francos y abiertos ${ }^{3}$. Por su parte la Unión fue esencialmente una entidad dedicada a impulsar el conocimiento y contacto recíproco entre los países iberoamericanos, con inclusión de Portugal. En las páginas de su órgano de prensa o en las intervenciones de sus dirigentes se apelaba reiteradamente a los vínculos entre pueblos de una misma raza y origen y se hizo habitual la idea de España como madre de naciones americanas y la relación familiar y filial que de ahí surgía. La historia común era raíz de un presente afín y compartido, de una «nacionalidad moral» basada en «una comunidad [...] de tendencias, de afecciones, de costumbres, de 
sentimientos y de nuestro inquebrantable cariño» (Murciano, 1894: 425); es decir, algo que tenía que ver ante todo con la dimensión emocional. No se alentaba desde España ningún tipo de irredentismo o afán de dominio político. Tan solo el reconocimiento de cierta primacía o preponderancia como matriz de aquel conjunto de naciones y una difusa pretensión de puente o vínculo con Europa, y tal fue la aspiración de fondo en las múltiples celebraciones del IV Centenario y su notorio propósito de integrar en la celebración a los países americanos. En cualquier caso, en las páginas de las publicaciones de la Unión Ibero-Americana, donde se habla habitualmente de Iberoamérica e incluso de América latina, no se encuentra hispanidad, y sus fines pudieran ser quizá mejor caracterizados como promoción del hispanoamericanismo que de la hispanidad en sí misma, un concepto en formación durante los años de mayor actividad por parte de la Unión y otras iniciativas análogas y de menor proyección.

Los centenarios del desencadenamiento de los episodios que llevaron a la independencia de las naciones americanas, aunque tuvieron ocasionales expresiones hispanófobas, fueron no obstante oportunidad para manifestar la pervivencia de vínculos culturales y afectivos que el mundo oficial resaltó con frecuencia tanto en España como en América. Especial fue el caso de la Argentina, cuya numerosa e influyente colonia española fomentó ese espíritu. En cierto modo, de aquella coyuntura derivó la oficialización de esa idea de unidad hispanoamericana. Durante la Primera Guerra Mundial, el presidente Irigoyen, volcado no solo en distanciar a su país de los alineamientos europeos sino también de salvaguardarlo de los intereses angloamericanos, y queriendo fomentar un panamericanismo hispano que contribuyera a ello, dio un empuje decisivo a aquella corriente tan arraigada en importantes sectores de opinión argentinos declarando el 12 de octubre fiesta nacional conmemorativa del Descubrimiento. Se adelantó con ello a una iniciativa similar que venía gestándose en España y que se materializó con la Ley de 15 de junio de 1918, siguiendo otros países en la adopción de igual norma y siendo varios los que de modo más o menos formal celebraban ya aquella fecha. De este modo cobró carta de naturaleza un auténtico lieu de la memoire catalizador de emociones identitarias. A diferencia de la disposición legal argentina, la ley española declaró la celebración del 12 de octubre «con la denominación de Fiesta de la Raza»" ${ }^{4}$ sustantivo que ya venía usándose.
Durante la dictadura de Primo de Rivera el concepto hispanidad cobró impulso utilizándose como instrumento de proyección de España hacia Europa, que se presentaba como «cabeza del bloque iberoamericano» (Sepúlveda, 2013: 1031). Jalones culturales relevantes de estos años serán la publicación en Madrid, ya desde 1919 y hasta a 1930, de la revista cultural de carácter nacionalista Raza, dirigida por Blanca de los Ríos, que se propuso como objetivo resaltar el prestigio de la cultura española tanto en nuestro país como entre las antiguas colonias hispanoamericanas y, por otro lado, la celebración de la Exposición Iberoamericana de Sevilla de 1929, un importante hito en la proyección del concepto a través del arte (Graciani, 2013: 133-146).

Durante la Segunda República, el debate sobre la hispanidad continuó a través de las aportaciones, entre otras, de Acción Española, Ramiro de Maeztu, y en menor medida de Ramiro Ledesma, Ernesto Giménez Caballero, José Antonio Primo de Rivera, siendo estas las fuentes de las que beberá el franquismo.

La idea hispanoamericanista encontró particular acogida entre el grupo de Acción Española, en cuya revista de igual título publicó Maeztu, en sucesivas entregas, los capítulos que formarán su libro Defensa de la Hispanidad. Este sector de intelectuales monárquicos y de catolicismo integrista acentuaba la identificación entre hispanidad y catolicismo en un paradigma puramente providencialista, trasmitiéndolo más tarde a la interpretación que de aquella idea se hizo oficiosamente durante el régimen de Franco. La hispanidad era, sustancialmente, una cuestión católica, y la historia de España en América una misión para la que había sido elegida por la Divinidad.

Otras de las fuerzas que contribuyeron a dotar al régimen de Franco de bases políticas e intelectuales asumían también el principio de la hispanidad, si bien de modo más general. Por ejemplo, el grupo de Ledesma Ramos, fundador de La Conquista del Estado en 1931, incluía en su manifiesto político, entre los diferentes puntos que resumían sus ideas y programa social y político, una escueta «Afirmación de los valores hispánicos» ${ }^{5}$, valores que no parecían especificados, como tampoco el alcance del adjetivo que pudiera referirse exclusivamente a España. Así se confirma en artículos posteriores de ese periódico, como el firmado por el propio Ledesma en el número de 14 de abril de 1931, donde expone los requisitos y objetivos del «Estado Hispánico» sin 
referencia alguna a los países americanos ${ }^{6}$. Más adelante, en 1935, este mismo autor, en un programa de transformación política general para España, incluyó entre los objetivos de política exterior «realizar una aproximación política, económica y cultural con todo el bloque hispano de nuestra América» (Ledesma, 1939: 106). De este modo cabe decir que en el jonsismo originario la cuestión de la Hispanidad como comunidad espiritual y cultural estuvo, en realidad, ausente o no fue en modo alguno objeto de atención particular. No era así en el grupo castellanista de Onésimo Redondo, con el que los primeros se fundirán. En las «Ordenanzas de las Juntas Castellanas de Actuación Hispánica», también de 1931 y solo en parte conservadas, se partía de una expresa afirmación hispanoamericanista: «Proclama la Junta su veneración por las grandiosas tradiciones patrias y la comunidad de raza y destino con las naciones ibéricas de ultramar» (Redondo, 1954: 247). Por último, la «Norma programática» de Falange Española, de 1934, en un punto en el que se sostenía la voluntad imperial y el rechazo de la mediatización extranjera, concluía con este párrafo: «Respecto a los países de Hispanoamérica, tendemos a la unificación de cultura, de intereses económicos y de poder. España alega su condición de eje espiritual de mundo hispánico como título de preeminencia en las empresas universales» (Primo de Rivera, 1970: 339). Nada de aquello iba a tener más que un alcance enunciativo, porque en la agitada y no muy larga vida de aquellas organizaciones fusionadas antes de la Guerra Civil española, no se desarrolló nunca un programa hispanoamericanista.

Por otro lado, ese tipo de apelaciones a la identidad hispana y transatlántica eran por aquellos años comunes a otros muchos escritores y políticos de distinta orientación. La República mantuvo, e incluso intensificó, la celebración del Día de la Raza, con actos no muy distintos a los conocidos con la Monarquía, si bien desarrollando un discurso en el que se contraponía la inoperancia del régimen caído a la efectividad con la que el nuevo decía querer enfocar las relaciones con las repúblicas americanas. Por ejemplo, uno de los más autorizados periódicos oficiosos escribiría: «algo común y entrañable une a cien millones de seres que hablan una lengua universal. La República sabrá canalizar en España ese sentimiento y llevarle por el cauce eficaz»? ${ }^{7}$. Aunque desde el primer momento el gobierno provisional dijo querer impulsar con sentido práctico las relaciones con los países hispanoamericanos ${ }^{8}$, su política exterior como la de los gobiernos que le siguieron, nunca muy concreta ni primordial, no materializó nada definido en esta materia.

El régimen de Franco concedió un lugar relevante a la idea de la hispanidad, íntimamente ligada a su vocación imperial; como ya había avanzado Ledesma Ramos, la hispanidad encerraba la idea de Imperio (Ledesma, 1931), aunque no fuese más que una ambigua pretensión de primacía cultural, incluso simbólica. Funcionalmente, la idea podría contribuir a fortalecer la identidad interna identificada con una España grande. Y de cara hacia el exterior "permitía mantener la ilusión de una proyección de la que el régimen carecía», presentándose como puente y vínculo con Europa (Sepúlveda, 2013: 1040), y obteniendo el apoyo de buen número de países americanos cuando el régimen instase su integración en los nuevos organismos internacionales de postguerra.

Pese a la defensa en los primeros años tras la guerra, por el sector de Falange, de una hispanidad algo más combativa basada en la afirmación de la voluntad de imperio y en un catolicismo militante, la proyección hacia América se vio limitada a la exaltación de los vínculos culturales y afectivos. «No era fácil -explica el profesor Saz Campos- ir mucho más allá de las ideas de unidad o comunidad espiritual de Maeztu o escapar de aquella cerrada identificación entre hispanidad y catolicismo que había establecido años atrás el cardenal Gomá». Vínculos que sobre todo se materializaron en «la defensa de la lengua y la cultura españolas» (Saz, 2003; Marcilhacy, 2014: 82). Dichas aspiraciones se concretaron en una serie de actuaciones institucionales, como la creación del Consejo de la Hispanidad en noviembre de 1940, dependiente del Ministerio de Asuntos Exteriores, al que sustituyó en julio de 1946 el Instituto de Cultura Hispánica. En el texto de la ley que le dio origen quedaron recogidos los vínculos y aspiraciones que el mundo oficial alentaba:

Cuando España alega en este amanecer de su vida futura, su condición de eje espiritual del Mundo Hispánico como título de preeminencia en las empresas universales, no pretende sino valorizar los ideales que le dieron ser en su día, constituyendo aporte generoso al caudal de la civilización.

El espíritu de la Hispanidad, que no es el de una tierra sola, ni el de una raza determinada, radica en la identidad entre su 
ser y su fin, en la conciencia plena de su unidad; condición de vida inexplicable, ya que para vivir los pueblos han de unirse siempre, no en la libertad, sino en la comunidad.

Impulsar este ideal, encauzarle, vigilarle, prestarle su máximo reflejo como política natural del Nuevo Estado, es la tarea que hoy se inicia con la creación del Consejo de la Hispanidad y la función que se le asigna trasunto de aquellas otras gloriosas tareas del Consejo de Indias, padre de leyes justas, ordenador de pueblos, creador de cultura, que fue cabeza rectora de nuestra política más allá de los mares. A él incumbirá conseguir que España, por su ideal ecuménico, sea para los pueblos hispánicos la representación fiel de esta Europa cabeza del mundo.

No le mueve a España, con esta actitud a que hoy da ser, apetencias de tierras y riquezas. Ante el espíritu materialista, que todas las ambiciona para si, ella nada pide ni nada reclama; sólo desea devolver a la Hispanidad su conciencia unitaria y estar presente en América con viva presencia de inteligencia y amor, las dos altas virtudes que presidieron siempre nuestra obra de expansión en el mundo, como ordenó en su día el amoroso espíritu de la Reina católica

\section{Hispanidad y arquitectura}

Desde sus primeros momentos y aún durante la Guerra Mundial, el régimen franquista persiguió el monopolio ideológico del país con vistas a su estabilización. En pos del reforzamiento de una cierta identidad nacional, teorizó, ya desde los años de guerra, sobre la creación de una imagen, de un "estilo», tema abordado en fecha temprana por numerosos autores (Laín, 1937: 164-169).

Así, por ejemplo, José Luis Aranguren, destacado filósofo y escritor por entonces en el inicio de su carrera, se planteaba idéntico problema en otro artículo. Consideró elemento medular en la concreción de ese estilo al arte, reconociendo su utilidad en la tarea de renacionalización que se proponía el régimen, dada su «profunda significación social, colectiva, nacional»:

Uno de los más punzantes problemas que se encuentra planteados de antemano la España que renace es el que apunta a lo que ha de ser su arte. Las nuevas falanges hispánicas, revolucionarias y tradicionales a un mismo tiempo, han apren- dido pronto algo que la agonizante clase burguesa no llegó a saber nunca bien: que el arte es esencial para el Estado (Aranguren, 1937).

El arte se planteaba a la luz de lo expuesto como algo puramente instrumental, como un distintivo de personalidad y espíritu colectivos, así como un vehículo para su exhibición y difusión.

Ya antes de la Guerra Civil, Ernesto Giménez Caballero, en su significativo libro Arte y Estado (1935), compendio teórico del ideario estético del fascismo español de anteguerra, subrayaba el poder del arte como instrumento ideológico, presentándolo como la mejor herramienta para impeler a las masas en su adhesión con el ideario del Estado, y entre todas las formas de creación era la arquitectura el arte mejor para expresar los valores de aquel:

Que la primacía del Estado era la primacía de lo arquitectónico, en su más amplio y etimológico sentido.

Arquitectonia: arte de Estado, función de estado, esencia del Estado.

Ante ella, las otras artes -como falanges funcionales- deberían disciplinarse para ocupar su rango de combate y ordenamiento (Giménez, 1935: 77).

La arquitectura es la más próxima al hombre, al conformar la imagen de sus ciudades, tratándose de espacios que le rodean y frecuenta cada día. Así, edificios representativos, de nueva construcción o históricos, se erigen en eficaces portadores de la ideología del poder, o al menos de su imagen. Tras una cruenta guerra, el régimen de Franco, consciente del valor de permanencia que la arquitectura tiene, de su carga simbólica y su eficacia propagandística, por encima de las demás artes, quiso convertirla en portadora y símbolo de su programa ideológico, poniendo todo su empeño en la tarea de reconstruir y reedificar aquello que había sido devastado, priorizando en estas intervenciones los edificios y conjuntos arquitectónicos asociados con periodos de gran significación histórica para la nación, fomentando así con sus actuaciones el culto a determinados espacios e inmuebles.

El régimen iba a servirse de la historia para legitimar su nuevo proyecto político e hizo una reinterpretación interesada del pasado, rescatando las elaboraciones decimo- 


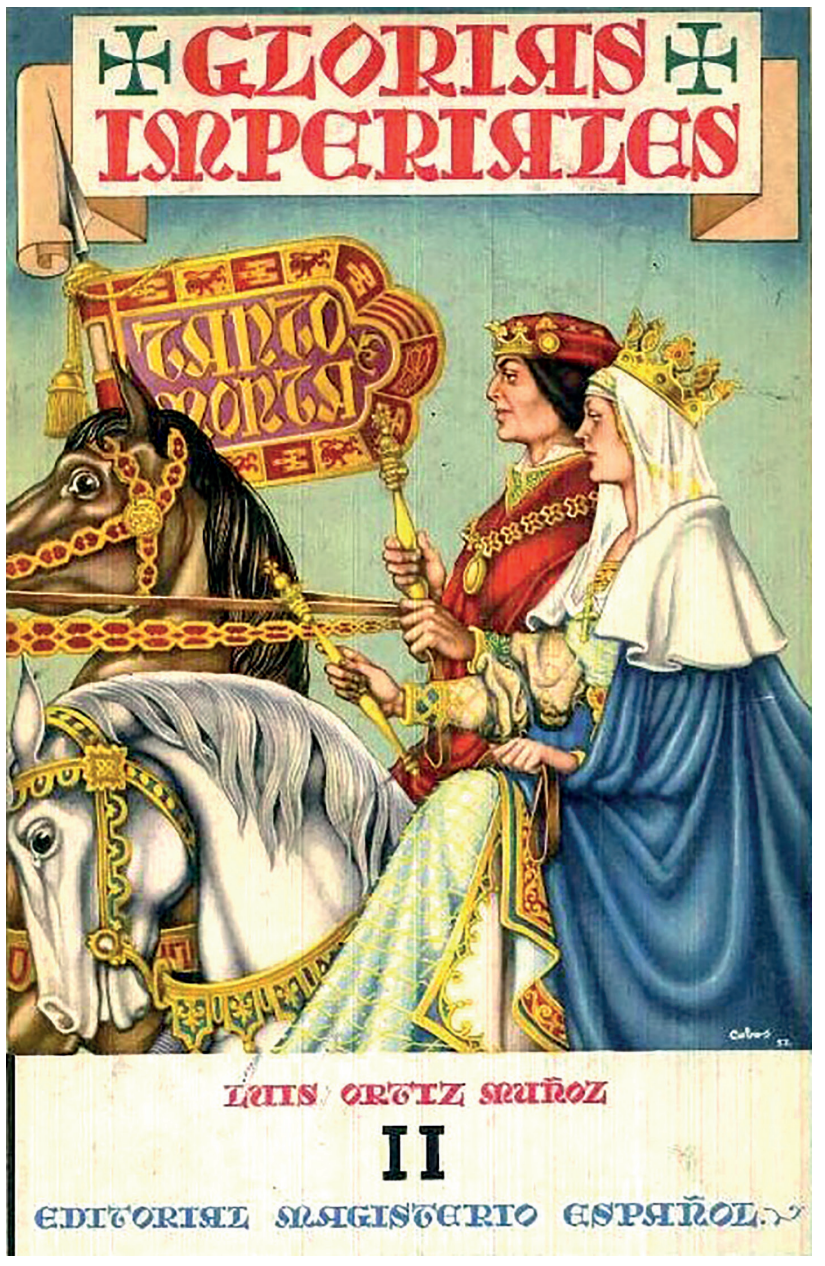

1. Cubierta del libro Glorias imperiales, autor Luis Ortiz Muñoz

nónicas más conservadoras y los hitos y mitos a los que aquel discurso había concedido mayor protagonismo, entre otros «el Cid, la Reconquista, la gesta de América, Felipe II, la Contrarreforma, la Independencia...», muy en la línea del relato planteado por Menéndez y Pelayo en su Historia de los heterodoxos españoles (1880-1882), alimentando así su discurso nacionalista ${ }^{10}$. Se iba a evocar un pasado heroico, una tradición "gloriosa», poniendo la mirada especialmente en la Edad Media y en los siglos XVI y XVII, centurias de mayor poder y expansión del Imperio español, presentando estos siglos como núcleo y esencia del pasado de la nación y buscando en ellos referentes y valores [1] y [2]. Iban a ser muchos los autores que se ocuparan de un tema tan central para la historiografía del régimen y que tuvo importantes

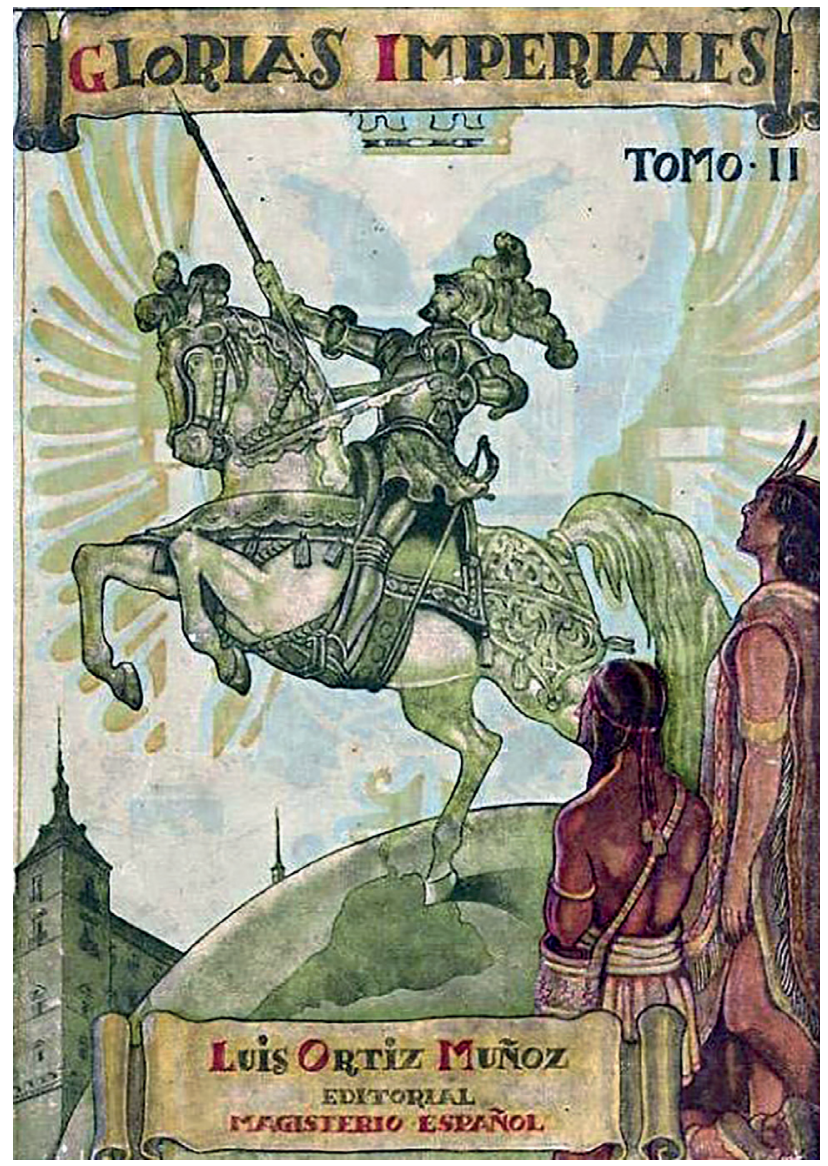

2. Cubierta del libro Glorias imperiales, autor Luis Ortiz Muñoz

consecuencias en las artes (Cabrera, 2012: 41-64). Esta filosofía de la historia iba a sustentar e inspirar la nueva arquitectura en la voluntad de encontrar cuál sería el estilo que más convendría al espíritu imperial español (Cabrera, 1998: 43-51, 82, 103-120).

Así, desde ámbitos oficiales, y a través de la literatura artística de los primeros años del franquismo, se alentó la proyección del concepto de imperio y de los valores que connotaba a las artes, haciendo evidente el interés del régimen por establecer un nexo con la época imperial, y vinculada a ello iba a estar la idea de la hispanidad. De la producción artística de los siglos XVI y XVII, cuyo rasgo más significativo era su hispanismo, su profundo carácter nacional, debían extraerse los códigos para elaborar un pretendido estilo oficial, en el que fueran visibles préstamos formales de los estilos artísticos de ese pasado, y se favoreció que determinados 
lugares y monumentos fuesen privilegiados en la tarea de la reconstrucción, como por ejemplo el Alcázar de Toledo, a la vez que otros se erigieron en verdaderos mitos e iconos que sirvieron como modelos de las nuevas construcciones, tal iba a ser el caso de El Escorial. Arquitectura y patrimonio iban a ser pues decisivos por el valor simbólico que tenían en la representación de la identidad nacional. La teoría imperial y sus postulados inspiraron y sustentaron muchas actuaciones y venían también a justificar el protagonismo que el régimen concedió a la idea de la hispanidad. Adquirían así un valor especial los principales edificios, conjuntos monumentales y ciudades vinculadas con el relato del descubrimiento del Nuevo Mundo: Granada, La Rábida, Guadalupe, Trujillo..., poniendo de manifiesto la apropiación ideológica que del patrimonio histórico realizó el nuevo Estado

Como apuntábamos más arriba, ya durante la guerra, el régimen había comenzado a organizar la reconstrucción del país dando prioridad a la recuperación de ciertos monumentos que tenían un alto valor simbólico para como la Cámara Santa de la Catedral de Oviedo, el Alcázar de Toledo, el Santuario de Nuestra Sra. de la Cabeza en Andújar, el Panteón Real del Monasterio de Poblet, etc., buscando con ello una clara rentabilidad política. La actividad de Regiones Devastadas y el contenido de revistas como Reconstrucción, publicada entre 1940 y 1953, son un buen ejemplo de estos intereses y de las actuaciones llevadas a cabo (García, Almarcha y Hernández, 2012).

Además, estos edificios y enclaves urbanos se convirtieron en marcos y escenarios privilegiados en los actos oficiales más representativos. El ritual asumió una importancia fundamental como expresión de mitos y materialización del ideario de los vencedores. Se trataba de manifestaciones multitudinarias que por su dramaticidad, emocionalidad, grandilocuencia y despliegue escenográfico, constituyen uno de los más efectivos métodos de persuasión colectiva, consiguiendo vincular al individuo con el nuevo statu quo, promoviendo su adhesión por su capacidad coactiva y persuasiva. Este tipo de actos, en los que se mezclaba lo religioso, lo militar, lo popular y la tradición, se prodigaron por tanto durante la guerra como en los primeros años del franquismo. Abundaron así celebraciones de la victoria, exaltaciones del trabajo, del Caudillo, misas de campaña, acciones de gracias..., en los que no faltaban desfiles patrióticos, militares, o procesiones religiosas, desplegándose en ellas un amplio repertorio artístico y pseudo-artístico al servicio del poder, transformando el espacio con arquitectura y escultura efímera, colgaduras, símbolos, emblemas e iluminaciones especiales en calles, plazas y fachadas. Todo ello se completaba con el atuendo (uniforme militar y de Falange, trajes regionales, etc.), los gestos, saludos, fuegos de artificio, etc., en una impactante puesta en escena (Cabrera y Pérez, 2004: 179-192) ${ }^{11}$.

En estos ritos la arquitectura asumirá papel protagonista, convirtiéndose, en numerosas ocasiones, en marco o escenario muy importante para inculcar en el imaginario colectivo el ideario del régimen. Proliferaron todo tipo de actos públicos (visitas oficiales, aniversarios, inauguraciones, celebraciones y fiestas locales o nacionales, etc.) para los cuales el Caudillo y otros dirigentes políticos seleccionaban como escenarios diferentes puntos de la geografía nacional y monumentos con fuerte carga simbólica. Estos eventos eran ampliamente publicitados en la prensa diaria, las revistas o la radio, dando cuenta del valor instrumental que para el régimen tuvo el patrimonio cultural. $Y$ entre todos, los edificios históricos relacionados con la hispanidad ocuparon un lugar relevante, tal es el caso de los escenarios vinculados con la gestación del descubrimiento, como Granada.

\section{La Capilla Real de Granada}

Esta ciudad se convirtió en uno de los lugares con un significado especial, pues se presentaba como símbolo de unidad política y religiosa al haber concluido en ella los Reyes Católicos la reconquista del país:

Unidad política y unidad religiosa: si sobre estos férreos pilares pudo forjarse el imperio en que jamás se ocultaba el sol, es lógico que acudamos a la conquista de Granada para buscar en este hecho cumbre la plenitud más perfecta y absoluta de aquellos factores esencialísimos de nuestro florecimiento futuro $[\ldots]$

España, fortaleza con tan vivificadora e indestructible unión política y religiosa no sólo consiguió el florecimiento interno, sino que se asomó de cara al mundo con ansias incontenibles de expansión, alumbrando nuevas tierras por las que derramó pródigamente la semilla fértil de su temperamento, reciamente cristiano, hidalgo y colonizador (Vicente, 1944: 7). 


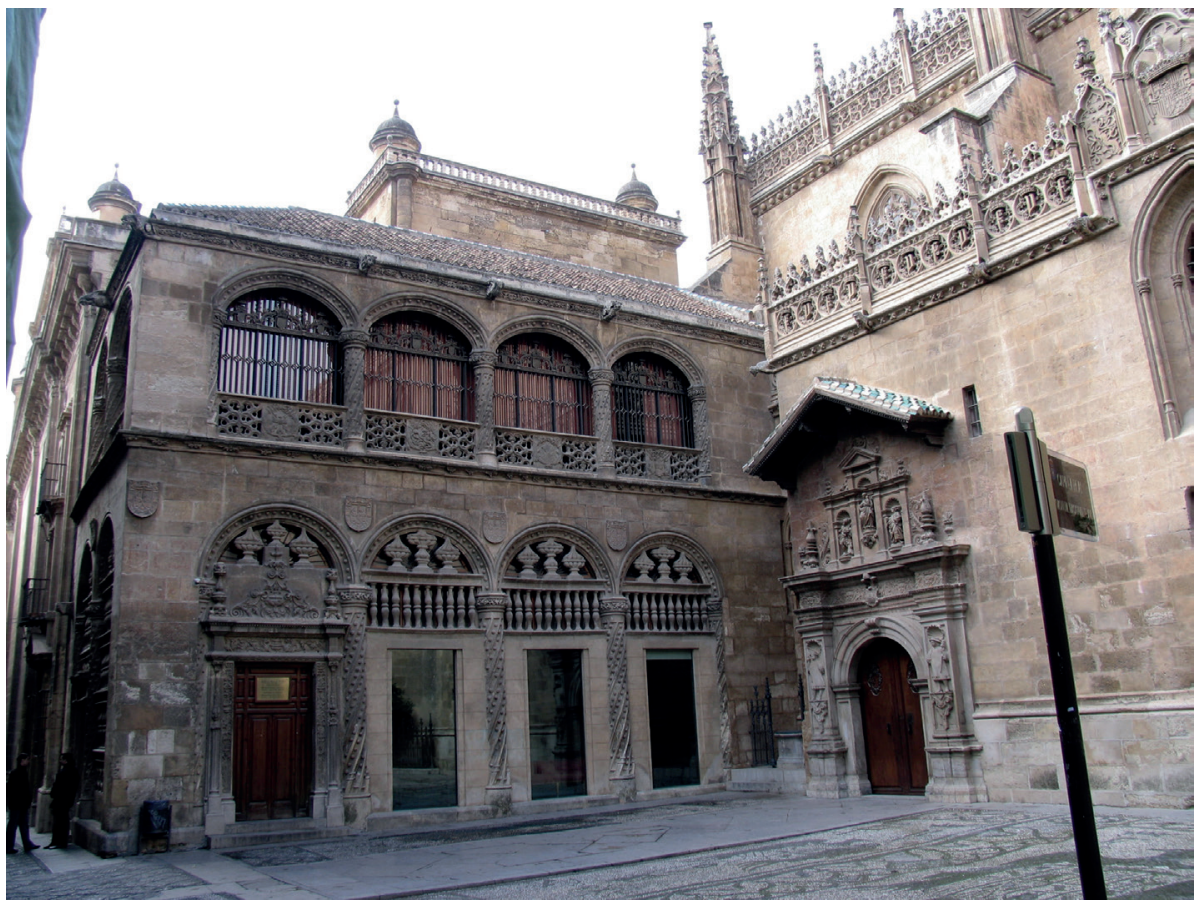

3. Capilla Real. Granada (foto de la autora)
La España imperial había dejado en Granada huellas muy valiosas e imperecederas, como el Palacio de Carlos $\checkmark$ o la Capilla Real, y en ella la cripta en la que reposaban los restos de los Reyes Católicos junto a los de Juana de Castilla, su esposo Felipe y los del príncipe Miguel. En este último conjunto monumental, de extraordinaria riqueza histórica y artística, los monarcas quisieron ver simbolizado, en su momento, la «consagración de la unidad política, territorial y religiosa que siguió a la ocupación de Granada». Iban a ser espacios, por tanto, representativos de importantes valores, por lo que las intervenciones en los mismos no se van a hacer esperar. Ya durante la guerra civil, Francisco Prieto Moreno, que ocupó los cargos de arquitecto conservador de la Alhambra y arquitecto de la Séptima Zona, había empezado su campaña de actuaciones en la Capilla Real [3], que durará varios años (Romero, 2010: 706-721), consciente del «valor histórico y representativo de la tradición y presente de España», como se puede leer en la memoria del proyecto (Prieto, 1941: 47-50). La redacción de la primera adecuación que llevó a cabo fue de octubre de 1937, y en ella acometió la reforma del acceso a la cripta y la eliminación del antiguo pavimento y decoración pictórica de la misma, intentando reintegrarla al estado primitivo, dejan- do visibles «las trazas originales de tan simbólico espacio, y recuperándose su esencia medieval» (Prieto, 1941: 47-50). Esta intervención se inauguró el 2 de enero de 1938, fecha de alto contenido simbólico también, pues a partir del año siguiente, tras su interrupción con la guerra, se iban a celebrar anualmente las fiestas conmemorativas de la reconquista de la ciudad, conocidas como Fiestas de la Toma de Granada (Garrido, 1998).

Los proyectos que siguieron a lo largo de la década se ocuparon de intervenir en la sacristía de la Capilla Real, destacando entre ellos el de septiembre de 1946, con el que se completaron las obras para ennoblecer el espacio y adaptarlo a Museo de los Reyes Católicos, lugar que debía convertirse en un referente a nivel nacional. El proyecto, que ya se había planteado en 1939, era en opinión de Gallego Burín «de urgente necesidad su realización [...] por el decoro de la Capilla, por lo que en España y en el mundo representa, y por lo que en el momento histórico que vivimos significa ese templo» (Romero, 2010: 716).

Para dar mayor realce a estas construcciones, la Dirección General de Bellas Artes aprobó, en 1943, otro proyecto de reordenación urbana del entorno de la Capilla Real, con el fin de mejorar la visibilidad del conjunto, dejando así 
4. Monasterio de Nuestra Señora de Guadalupe (foto de la autora)

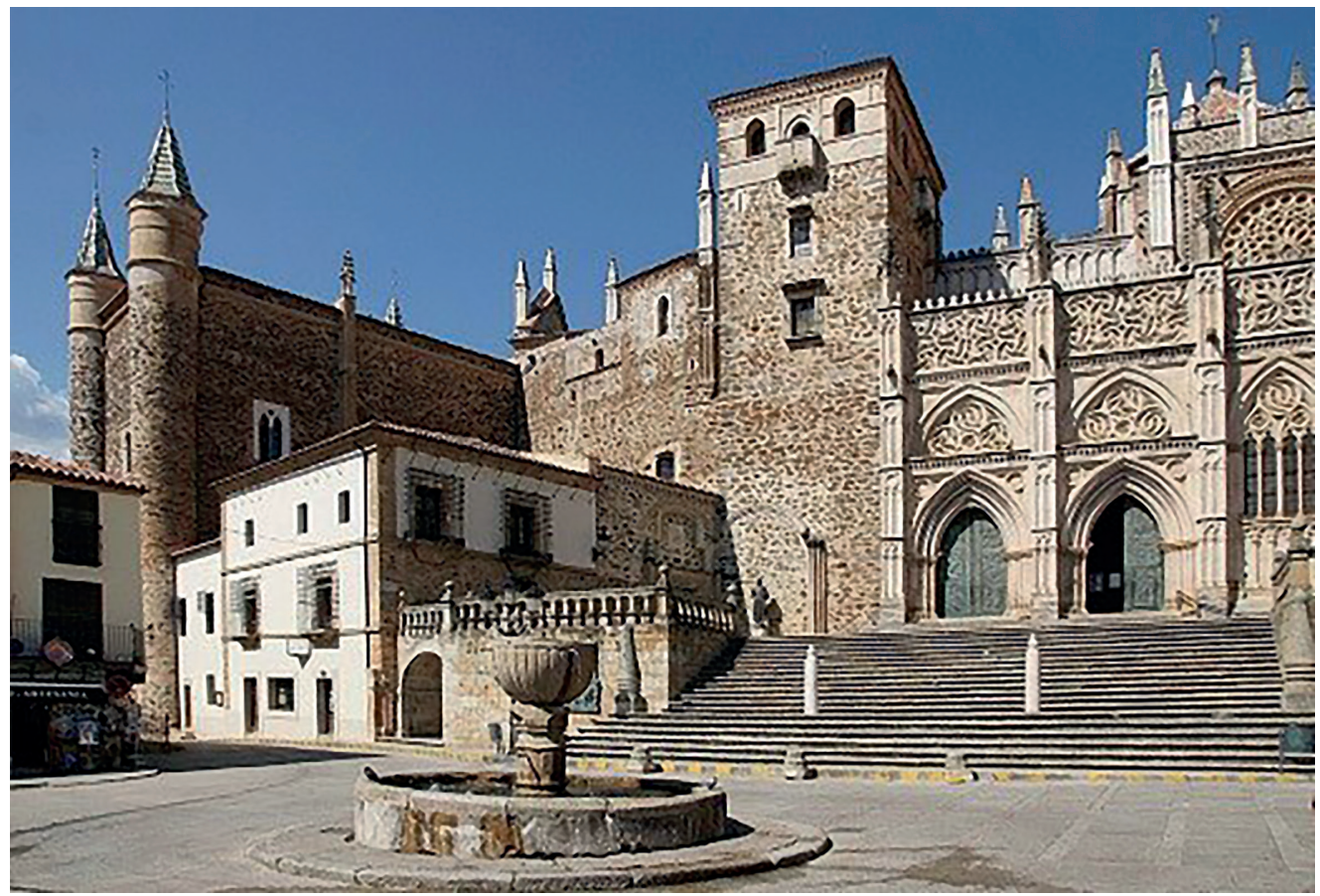

«libre la contemplación y lucimiento como corresponde a una obra de su valor» ${ }^{12}$

La Capilla Real, el Museo y su entorno urbano, se convirtieron, por tanto, en escenario de especial significación para celebraciones -y pese a que el conjunto se alzó después de las capitulaciones con Colón-, algunas vinculadas a la exaltación de la hispanidad, por estar ligados estos espacios y los acontecimientos históricos y personajes asociados a ellos con los inicios de la colonización de América, como lo ponen de manifiesto algunos de los muchos actos organizados. Así, en 1948, con motivo de la constitución de la Asociación Cultural Iberoamericana, los delegados universitarios sudamericanos visitaron la tumba de los Reyes Católicos entregando en el solemne acto las banderas enviadas por sus países para ser depositadas en el museo $^{13}$. Y ya antes de terminar la guerra, el 2 de enero de 1939 se conmemoró el 447 aniversario de la Reconquista de Granada por los Reyes Católicos, que, como se ha visto, a partir de esa fecha siguió celebrándose con puntualidad todos los años, tras su interrupción en los años de la guerra. La prensa nacional subrayó su vistosidad, esplendor y solemnidad reproduciendo imágenes de la procesión cívica o del momento en que fue tremolado el estandarte de la ciudad en la Capilla Real ${ }^{14}$.

\section{El Monasterio de Nuestra Señora de Guadalupe}

Otro monumento con una importante carga simbólica vinculado con la historia, la identidad nacional y la hispanidad, fue el Monasterio de Nuestra Señora de Guadalupe [4], que había sido declarado Monumento Nacional en 1879, y fue reconocido, además de por sus valores artísticos, por su vinculación con momentos relevantes de la historia nacional, como se puede leer en el texto de la declaración: «Considerando que el referido Santuario, tanto por su mérito artístico como por su historia y recuerdos gloriosos que encierra, es uno de los monumentos más dignos de conservación bajo todos los conceptos» (Mogollón, 2012: 249; Hernández, 2012: 106).

Ya en las décadas que preceden a la guerra puede constatarse la proyección simbólica de este conjunto arquitectónico. En 1928, con motivo de los preparativos de la Coronación de la Virgen, que se celebró en el Día de la Raza, se enfatizó su importante vínculo con el descubrimiento de América en la prensa:

Aquí ha palpitado más reciamente que en parte alguna el corazón de España. ¿Dónde, sino en este monasterio, firmaron 
los Reyes Católicos la carta que hizo efectivo el viaje de Colón para el descubrimiento de América? [...] En el sentido españolista, significará la reintegración del alma nacional a uno de los valores más profundamente raciales y más certeramente constructivos, pues con el nombre de Guadalupe por bandera, Pizarro y Hernán, Valdivia y Núñez de Balboa, ganaron tierras para el Rey y almas para Dios ${ }^{15}$.

Complejo monumento y de complicada tutela, la primera fase de las restauraciones se acometió antes de la Guerra Civil, de la mano de Menéndez Pidal (Martínez, 2008: 266-272), quien en 1923 recibió del Ministerio de Instrucción Pública y Bellas Artes el encargo de restaurarlo. Después de la contienda, tras ser nombrado arquitecto conservador de Monumentos de la Primera Zona en 1941, retomó los trabajos en el conjunto, continuando su vinculación con el mismo hasta 1975. El régimen además reconoció su trabajo antes de la guerra en el Monasterio con la concesión de la Primera Medalla Nacional de Arquitectura en la Exposición Nacional de Bellas Artes de 1941, contribuyendo de este modo a destacar el valor simbólico del recinto (Mogollón, 2012: 249).

Desde los primeros años del franquismo su protagonismo como escenario de visitas oficiales y marco de celebraciones fue habitual. El mismo jefe del Estado lo visitó en un viaje a Cáceres y, en 1945, el ministro de Asuntos Exteriores, Martín Artajo, ofreció al cuerpo diplomático americano acreditado en Madrid una excursión al Monasterio, contribuyendo a poner de manifiesto los vínculos con América ${ }^{16}$.

El empleo de monumentos como marco para celebrar acontecimientos culturales se iba a ir extendiendo. Junto a Guadalupe, también en Extremadura otros escenarios ligados al descubrimiento y a los conquistadores ocuparon un lugar destacado. Tal es el caso de la ciudad de Trujillo. Convenientemente engalanadas, sus calles, su plaza mayor presidida por la escultura ecuestre de Pizarro (donación norteamericana de 1922), con plinto de Pedro Muguruza, acogieron los actos organizados por el Consejo de la Hispanidad en homenaje al conquistador del Perú, Francisco Pizarro, con motivo del IV centenario de su muerte ${ }^{17}$. Entre ellos destacan la procesión cívica organizada en la plaza y la entrega simbólica de la espada del fundador del Perú por el ministro plenipotenciario del país americano al canciller del Consejo de la Hispanidad, Manuel Halcón, además de servicios religiosos, discursos al pie de la estatua de Pizarro y desfile de las fuerzas del ejército, ofrenda de una corona de laurel en la parroquia de Santa María -donde fue bautizado Francisco Pizarro- y visita al solar de la familia, «futuro museo del conquistador en Trujillo", más un concierto de danzas y cantos regionales extremeños. Entre los asistentes figuraron el presidente del Consejo de la Hispanidad, el ministro del Perú en España, los ministros del Ejército, Marina y Aire además de los miembros del Consejo de la Hispanidad.

En 1944, la Sección Femenina del Movimiento también escogió este escenario, «hito de la mejor historia», para la celebración de su Octavo Consejo Nacional, «en mitad de Extremadura, cruzada de vientos y ufana de conquistadores», evento para el que el pueblo se adornó de banderas y el templo mostró sus mejores galas. ${ }^{18}$

\section{El Monasterio de la Rábida}

Entre los enclaves ligados con el descubrimiento de América y la hispanidad, los denominados lugares colombinos, como el Monasterio de la Rábida, recibieron trato de favor. Washington Irving, fascinado por la figura de Cristóbal Colón y por la aventura descubridora, había contribuido a darlos a conocer en Europa. El Monasterio fue declarado Monumento Nacional en 1856, y ya en 1914 Ricardo Velázquez Bosco había acometido una restauración, publicando una memoria de la intervención. Tras la Guerra Civil, el edificio se encontraba bastante deteriorado, como se denunció en la prensa: «En la actualidad el monasterio hallábase muy abandonado y con una serie de anacronismos arquitectónicos en fuerte contraste con la significación que debe tener» (Fontenebro, 1944: 9).

El conjunto fue objeto de una serie de intervenciones promovidas por el Consejo de la Hispanidad, dirigidas por Martínez Feduchi, las cuales tuvieron como finalidad «la dignificación definitiva de un rincón geográfico glorioso, de un ambiente y de una época inmortal para la historia española, [...] ningún trabajo mejor que este para ser llevado adelante con prisa, con devoción y con orgullo». Se destacaba así el valor simbólico del lugar. En la prensa se hizo una descripción somera de las intervenciones, trascendiendo información de los proyectos a realizar:

El actual Museo Colombino y los locales de la Sociedad Colombina también se mejoran y ordenan, dándose a la sala del 
Museo una prestancia que hoy no tiene. En un gran lienzo de pared se pintará un mapa inspirado en el de Juan de la Cosa, donde se marquen los itinerarios de los viajes de Colón, y el centro de la sala será ocupado por una reproducción de la Santa María, tomada del Museo Naval de Madrid (Fontenebro, 1944: 9).

El Monasterio fue declarado Primer Monumento Histórico de los Pueblos Hispánicos en 1949, en el I Congreso Hispanoamericano de Historia celebrado en Madrid en octubre, subrayando su especial vínculo con la hispanidad. Lugar central ocuparon en este conjunto arquitectónico los frescos de Daniel Vázquez Díaz, artista que tras la guerra fue objeto de numerosos reconocimientos y exposiciones, prodigándose las páginas dedicadas a su obra por la prensa especializada [5]. Sirva como muestra la exposición de bocetos y dibujos del pintor «correspondientes a los admirables frescos del Monasterio de la Rábida», que fue instalada en los patios del Ministerio de Asuntos Exteriores. Con motivo de la misma Francisco de Cossío escribía:

Hace diez años Daniel Vázquez Díaz terminaba sus frescos, en el Monasterio de la Rábida, conmemorando la inicial milagrosa del Descubrimiento; ahora, en la fecha del 12 de octubre, se vuelven los ojos hacia esta obra, que tan hondo sentido tiene, dentro de nuestros anhelos de hispanidad. Nos hallamos, pues, en trance de revisión de ideas, sentimientos y teorías, y no solamente en el orden puramente intelectual, sino en el plástico. En este aspecto, la exposición de los cartones, dibujos y bocetos de la Rábida, a diez años fecha, tiene ahora una rara actualidad, en este instante en que los españoles se acuerdan de que el Atlántico fue la vía maravillosa en una gigante empresa de expansión (1940: 3) ${ }^{19}$.

En los años cincuenta las intervenciones continuaron, como se desprende de los proyectos abordados en las reuniones de la Real Sociedad Colombina Onubense, entre los que figuraron: edificar en La Rábida la Casa Museo de América y un jardín de aclimatación de la flora americana, acordándose encargar un anteproyecto; restaurar la Fontanilla de Palos de la Frontera, «donde hicieron aguada las históricas carabelas descubridoras de América, obra que pudiera ser inaugurada el 15 de marzo próximo»; gestionar con el «Instituto de Cultura Hispánica la adquisición de la casa de

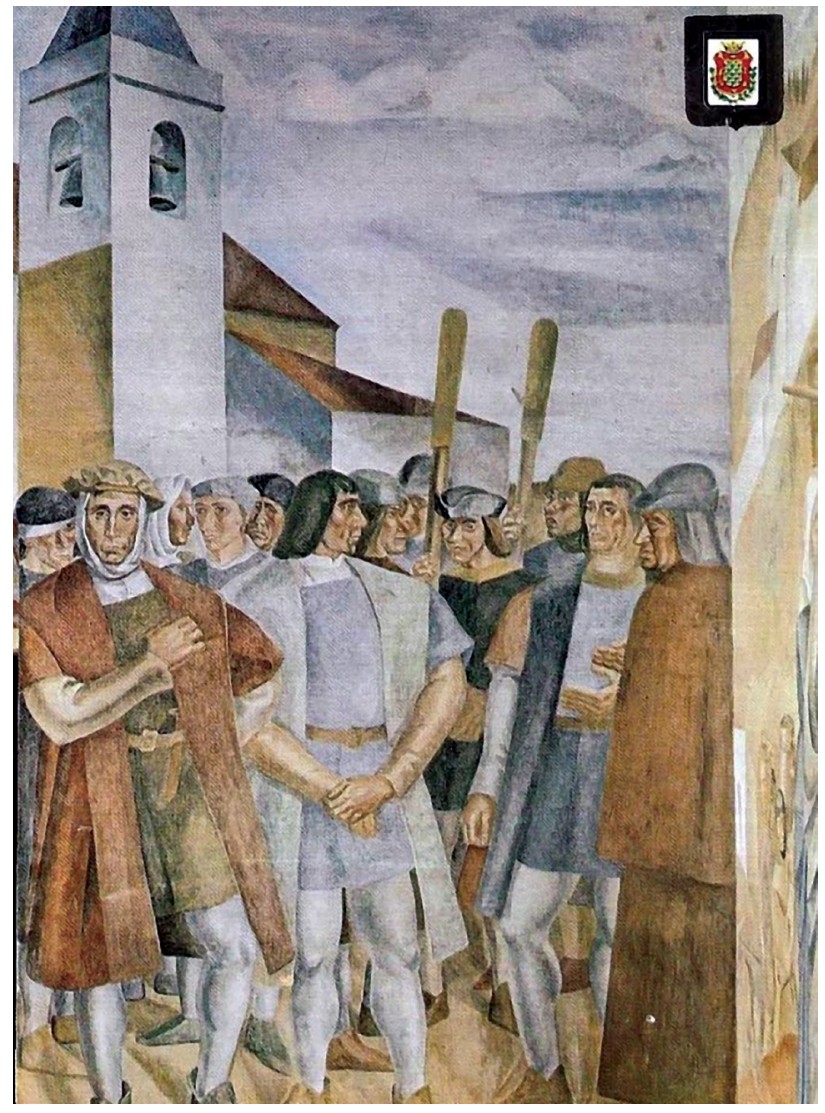

5. Postal que reproduce un detalle de los frescos de Daniel Vázquez Díaz. Monasterio de la Rábida

Martín Alonso, en Palos, para convertirla en Casa Museo de los Pinzones»; también se planteó la «erección en Palos del Monumento a Martín Alonso Pinzón»20.

Huelva, La Rábida, Palos de Moguer o Palos de la Frontera, «lugares colombinos, cuna del descubrimiento de América, [...] que demostraron al mundo el espíritu de una raza, paladines, al fin, de los destinos universales de España», fueron destinos preferentes de eventos oficiales, como los actos conmemorativos del «Cuatrocientos cincuenta aniversario de la salida de las naves descubridoras» en junio de $1942^{21}$. Además del desfile de las tropas a las que pasó revista el Capitán General del Departamento naval de Cádiz, representando al Jefe del Estado, «en el patio del Monasterio de la Rábida se celebró un acto literario», ornado para la ocasión con banderas de los países hispanoamericanos, y también en la nave que reproducía la carabela Santa María «fue izado, en solemne ceremonia evocadora, el pendón de 
Ios Reyes Católicos»22. Se celebraron igualmente todos los años las conocidas como Fiestas Colombinas, en las que se preparaban fastuosas iluminaciones de los monumentos, calles y plazas, se organizaron corridas de toros, competiciones deportivas, verbenas, juegos florales y espectáculos teatrales.

\section{La basílica del Pilar}

La basílica del Pilar [6] fue otro de los edificios religiosos que se convirtieron en templos de la hispanidad. Se trata obviamente de un lugar especialmente simbólico, en el que se centralizó la celebración del 12 de octubre. Aragón había sido una región muy castigada durante la guerra, sufriendo las consecuencias de ser frente y las duras batallas del Ebro y Teruel, por lo que adquirió un fuerte valor simbólico. Pensemos en el potencial propagandístico de las ruinas de Belchite, convertidas en icono de la devastación de la guerra y del «terror rojo», y en los numerosos «pueblos adoptados» por Franco, poniendo de manifiesto la proximidad «afectiva» del régimen con la región (Gómez, 1940: 1; Hernández, 2008: 151-198).

La basílica o Santo Templo Metropolitano de Nuestra Señora del Pilar en Zaragoza había sido declarada Bien de Interés Cultural en junio de 1904 por decreto del Ministerio de Instrucción Pública y Bellas Artes. Durante los primeros años del franquismo el Cabildo acometió algunas actuaciones en él, como la redecoración en piedra que diseñó para la fachada exterior de la plaza del Pilar el arquitecto del templo, Teodoro Ríos Balaguer, llevada a cabo entre 1942 y 1954.

El 29 de diciembre de 1939 el Ministerio de Gobernación resolvió declararlo «Templo Nacional y Santuario de la Raza»23. Para conceder dicha consideración el Ministerio había solicitado sendos informes a las Reales Academias de la Historia y de Bellas Artes. La primera de ellas argumentó, entre otras razones, en favor de la concesión de este preciado título, su vínculo con Santiago el Mayor, al que según la tradición, en su predicación en Zaragoza se le había aparecido la Virgen habiendo levantado en el lugar una «modesta capilla», germen de la futura basílica. Además, se atendía igualmente, a la innumerable serie de mártires y confesores que allí dieron su vida por Dios. El documento subrayaba los vínculos con el sagrado lugar de Fernando el Católico, Carlos $\vee$ y Felipe II, su valor arquitectónico y las joyas artísticas que contenía, de artistas como el "genio inmortal de Goya», poniendo especial énfasis en su consideración de «Santuario de la Raza». Fueron, por ello, numerosos los estudios y ensayos que en esos años lo vincularon con la hispanidad y las señas de identidad nacionales:

La sola evocación de una fecha, 12 de octubre, solemnemente consagrada por la Iglesia para perpetuar la memoria de la milagrosa aparición de la Virgen a Santiago el Mayor, lleva como inevitablemente aparejada la del mismo día de 1942, en que, al alumbrar España un nuevo mundo, encumbró la Raza a la más elevada cima a que ha podido ascender ningún otro pueblo del planeta.

Por ello, el 12 de octubre fue la jornada elegida por nuestros Gobiernos y los de la América Española para celebrar la fiesta mayor de su fraternidad racial, es decir, la efeméride gloriosa en que sobre un mismo Pilar reafirmaron periódicamente las gentes hispanas, con su fe, el recuerdo de su máxima empresa pretérita y la confianza de sus destinos. ${ }^{24}$

La Academia de Bellas Artes destacó lo que aportaba el Pilar a la lista de templos que poseían esa consideración, poniendo de manifiesto el valor simbólico de estos monumentos:

[...] el Santiago de las europeas peregrinaciones, dicta perennemente la lección de la universalidad. La Covadonga de las apretadas reconquistas archiva el secreto de la continuidad, el Guadalupe de las oceánicas expansiones cifra la imperialidad generosa. El Pilar añade a tales esencias una ley de reciedumbre bravía que regará siempre los ritos y las piedras con la sangre caliente de lo popular ${ }^{25}$.

La basílica igualmente sería escenario de un gran número de actos, viéndose transformada, junto a su entorno, por diferentes escenografías, especialmente durante la Fiesta de la Hispanidad, el 12 de octubre, que siguió festejándose en posguerra, celebración de cuyo sentido, despliegue y solemnidad se hacía eco la prensa:

La llamada Fiesta de la Hispanidad en el nuevo Estado español ha dejado de ser una fiesta protocolaria y fría, vestida con una retórica, hueca de sentido, para convertirse en una conmemoración viva, en la que el español, al darse cuenta 
de lo que fue, hinca su planta en el suelo para lanzarse a un futuro de gloria ${ }^{26}$.

La primera celebración del 12 de octubre en la «nueva España» tuvo lugar en Zaragoza en 1939, el denominado «Año de la Victoria». Esa elección sirvió para conectar la festividad del Pilar y enlazar la hispanidad con una ciudad que desde principios del siglo anterior simbolizaba la independencia nacional. Fue el primer acto oficial de gran envergadura organizado por el régimen después del conocido como Desfile de la Victoria y, presidido por Franco, reunió a los representantes de los países hispanoamericanos. En diciembre de ese mismo año, Franco declaró la basílica «Templo Nacional y Santuario de la Raza» ${ }^{27}$.

La celebración, dando continuidad a las conmemoraciones ya habituales antes de la guerra, se extendió a todo el territorio nacional e incluso al extranjero (Roma, Londres, México). Sirvan de ejemplo los actos preparados en Madrid en 1940, en los que estuvieron muy presentes los países americanos y en los que todas las artes entraron en escena. Entre ellos figuraron: Rosario de la Aurora a las 5 de la mañana que «marchó en peregrinación de desagravio» desde la Cibeles al Cerro de los Ángeles con la Virgen del Pilar, donde se celebró una misa; Misa de campaña en la plaza de la Armería a las 11 de la mañana, presidida por Franco, al que siguió el desfile militar de las «fuerzas de la Guardia Civil de la Casa Militar de Su Excelencia», acto de coronación de la imagen de la Virgen del Pilar en la basílica pontificia de San Miguel, finalizado con misa solemne; en San Francisco el Grande celebración de una misa «rezada organizada por el Ministerio de Asuntos Exteriores, por los héroes y mártires hispanoamericanos de nuestra Cruzada» oficiada por el obispo de Madrid-Alcalá:

Después de alzar, en cuyo momento se interpretó el Himno Nacional, el general Millán Astray subió al presbiterio, y, previa autorización de la autoridad eclesiástica, pronunció un vibrante y emotivo discurso, glosando la gesta de los hermanos de hispanoamérica que ofrendaron su sangre en la Cruzada Española ${ }^{28}$.

A continuación salió de la iglesia de los Jerónimos una solemne procesión de la Virgen del Pilar y por la tarde se inauguró la Exposición de la Hispanidad, en la que se le-

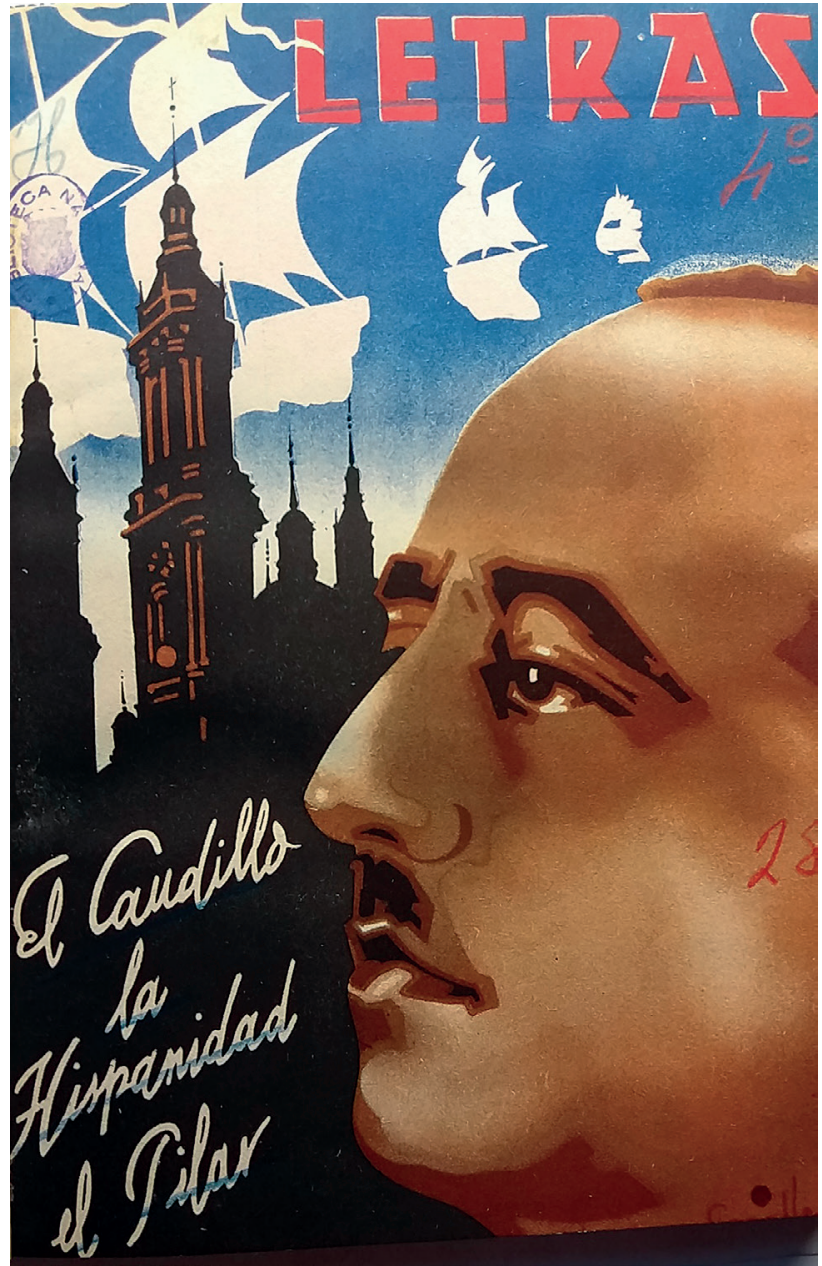

yeron discursos del consejero nacional Eugenio Montes y el embajador del Perú, y se cantó el Cara al sol. Por la tarde se organizó una solemne sesión del Instituto de España en la Real Academia de la Historia, presidida por el Ministro de Educación Nacional, el marqués de Lema, director de la Academia, el director de Bellas Artes, conde de Romanones, Julián Palacios, el secretario perpetuo del Instituto de España, Eugenio d'Ors y López Otero y se hizo referencia a los últimos trabajos del Instituto; Antonio Ballesteros, miembro de la Academia de la Historia, procedió a leer un trabajo sobre «España y Cristóbal Colón en el descubrimiento de América». La jornada terminó con un banquete al cuerpo diplomático de los «países hispanoamericanos» y un concierto en el Teatro Calderón. 


\section{El Museo de América}

Otro capítulo de interés en la repercusión que la hispanidad tuvo en la arquitectura de los primeros años del franquismo fue la edificación de nuevos espacios, y en esta línea hemos de destacar la creación del Museo de América en abril de 1941, absolutamente vinculado con la memoria del descubrimiento, con la intención de dotar a la capital española de un lugar de exposición para sus ricas colecciones:

[...] el Ministerio de Educación Nacional instituye el nuevo Museo de América, palacio donde las culturas indígenas y coloniales de cada país -esparcidas por las diversas salas en mapas, vitrinas, monetarios, cerámica, pintura, escultura, manuscritos e impresos de ediciones príncipes- pregonan la unidad racial e idiomática. La gran familia hispanoamericana afirma, en las aportaciones del Museo, el blasón de estirpe (Castro, 1945: 19).

El museo tenía como misión -según se lee en el decreto- ofrecer al gran público una presentación de los pueblos autóctonos y de la «gesta heroica del descubrimiento y colonización americana que estuviera libre de las interpretaciones extranjeras presuntamente desfavorables» (Moya y Martínez, 1943: 411-416)29.

Se inauguró en julio de 1944 [7] en una sede provisional, en varias salas del Museo Arqueológico Nacional, y el fondo inicial lo constituyeron las colecciones de etnografía, arqueología americanas y arte colonial existentes en el Museo Arqueológico, pero la intención era incrementarlas con:

[...] objetos de arte americano o de interés histórico adecuado, y, además, con reproducciones, vaciados, croquis, planos, mapas, fotografías, dibujos, maquetas, y cuantos medios en sí puedan servir para hacer más expresivas las instalaciones. También figurarán las manifestaciones artísticas modernas de los pueblos americanos. Por eso no se llama a este Museo de Indias, sino de América, y no tiene su tope en las fechas de la independencia americana, sino que ha de continuar recogiendo y estudiando muestras de su arquitectura, de su pintura, de su escultura, de su música, arte industrial y folklore como productos espirituales, en los que sigue latiendo el genio hispano ${ }^{30}$.
Al acto de inauguración asistió, junto a la directora del Museo, Pilar Fernández Vega, el subdirector y miembros de la Junta, el ministro de Asuntos Exteriores, general conde de Jordana, el ministro de Educación Nacional, Ibáñez Martín, el nuncio de su Santidad y los embajadores de Argentina y Chile, los ministros plenipoteciarios de Brasil, Perú, El Salvador, Venezuela, Nicaragua y Ecuador, entre otras autoridades y se dio paso a los discursos. El ministro de Educación Nacional, en su intervención, exaltó la trascendencia del acto, destacando las piezas del museo y los lazos de unión, comprensión y hermandad «entre las naciones que componen la Hispanidad»:

El nuevo Museo que inauguramos hoy quiere ser exponente de la riqueza espiritual de la América española, además de querer ser igualmente reflejo del arte y de la vida precolombinos. La América de ayer y la América de hoy han de aparecer unidas en las salas del Museo como testimonio vivo de una gigantesca labor pasada y de una profunda vitalidad actual ${ }^{31}$.

Este espacio museístico quería ser homenaje «a una labor que pertenece a la mejor historia del mundo», y en él -a decir del ministro- iba «implícita también otra afirmación: la de que España mira, con delectación a aquellos países que caminan por la ruta de los grandes ideales de fe y de espiritualidad que han iluminado al mundo» 32 .

Abriría con siete salas «donde se recoge el ejemplar testimonio de nuestra labor colonizadora en el Nuevo Mundo» (Barberán, 1945a: 21)33. En la prensa se resalta esta empresa como ejemplo del «poder creador del pueblo hispano», de la «unidad moral y política de nuestro pueblo» y muestra de «nuestra misión espiritual y cultural en América». Se destacaba especialmente la sala D del museo, en la que se plasmaban seguía el discurso- «nuestros mejores afanes colonizadores»:

¿Dónde aparece la obra de España? Aparece en el conjunto de esta sala y de la manera más honda: o sea como fruto de un mestizaje de sangres que da lugar a la soldadura de los vínculos raciales más dispares en beneficio, pues, de la gran tarea espiritual que, ante todo, suponía nuestra empresa colonizadora (Barberán, 1944: 19).

La construcción del nuevo edificio, y actual sede, comenzó en 1943 y el proyecto corrió a cargo de los arqui- 
tectos Luis Moya y Luis Martínez-Feduchi que, siguiendo la inspiración del decreto fundacional, pretendieron sugerir con su diseño «la idea de la labor misionera y civilizadora de España en América», proponiendo un estilo «historicista y neocolonial con un arco en la fachada, una torre que sugiere las de las iglesias barrocas americanas y una disposición conventual» (Vázquez, 1969: 105-112)34. La construcción no se terminó hasta 1954, procediendo a inaugurarse en 1965. El conjunto se completaría con la edificación en sus proximidades y en las mismas fechas de la sede del Instituto de Cultura Hispánica, en la Ciudad Universitaria y también del arquitecto Luis Martínez-Feduchi, hoy Agencia Española de Cooperación Iberoamericana.

Otros edificios de nueva planta se levantaron a lo largo de los años cuarenta y en la década siguiente, con menor valor patrimonial y sin la carga simbólica de los tratados hasta ahora, pero que ponen de manifiesto y recuerdan el papel central que seguirán teniendo para el Régimen Hispanoamérica y la idea de la hispanidad, entre ellos levantados en Madrid: el edificio del Banco Hispanoamericano, en 1947, proyecto del arquitecto Manuel Ignacio Galíndez Zabala; el Colegio Mayor Hispano Americano Nuestra Señora de Guadalupe, en 1948, también en la Ciudad Universitaria y de Luis Martínez-Feduchi; la Barriada de viviendas Hispanoamericana, en 1949, viviendas de protección oficial en el distrito de Chamartín, de los arquitectos Pedro Antonio Alapont Calvo y José Pellicer Gambús; la Basílica Hispanoamericana de Nuestra Señora de la Merced, en 1949, interesantísimo e innovador proyecto dentro de la arquitectura religiosa del momento, como también era el caso de la Basílica de Aránzazu, diseñada por los arquitectos Francisco Javier Sáenz de Oíza y Luis Laorga Gutiérrez y que incorporaba elementos de nuestra arquitectura colonial adaptados a los aires de modernidad que presentaba el edificio ${ }^{35}$, como innovador en diseño fue también el Colegio Mayor Tecnológico Hispanoamericano de Santiago y su capilla, en 1954, del arquitecto José Luis Fernández del Amo.

Para concluir nuestro estudio, es importante volver a insistir en el papel que el Estado asignó al arte y al patrimonio, la función patriótica que se le atribuyó y la eficacia que se esperaba de ellos como instrumentos. Tales cuestiones fueron explicitadas por la prensa desde los primeros años del régimen:

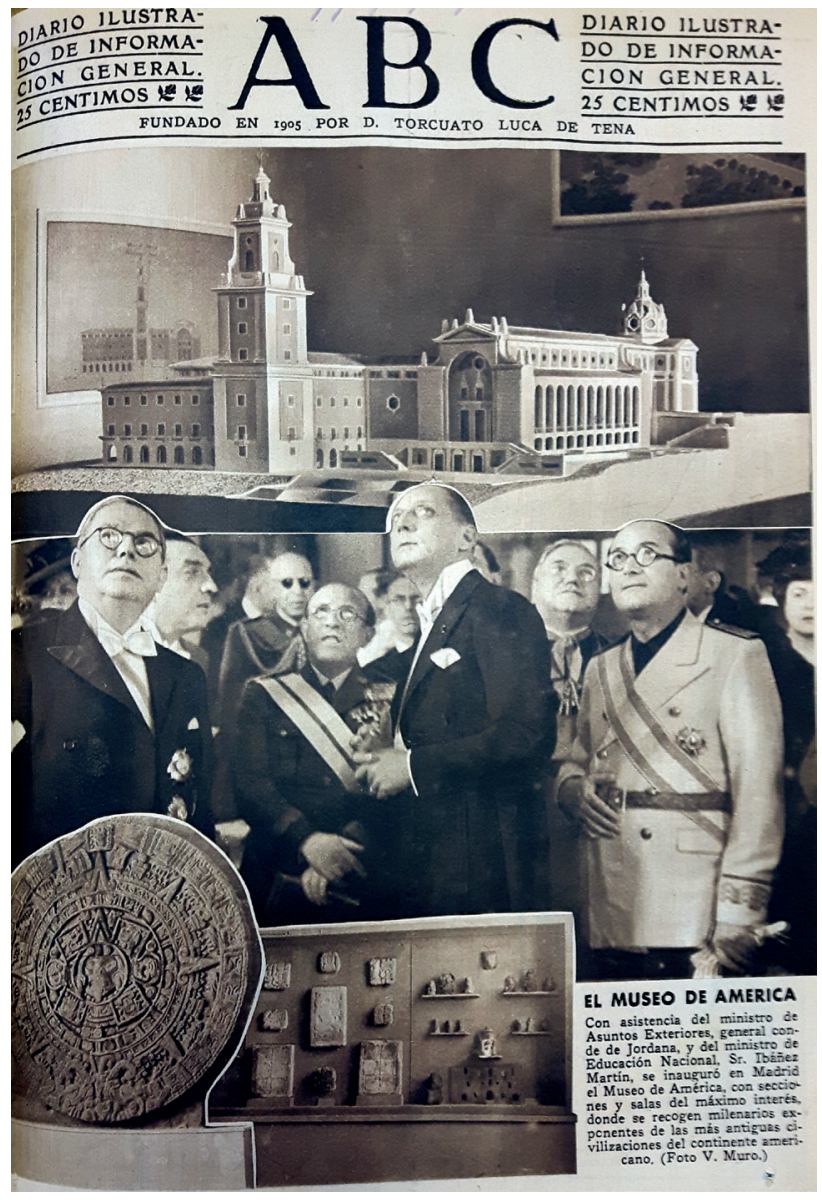

7. Abc de Madrid, 14 de julio, 1944

España, lañada de parte a parte por tantas espadas victoriosas, cuando llegó la hora de la reconstrucción del patrio solar se encontró con infinidad de acervos de arte, a los que amontonó la lucha, que había que colocar adecuadamente. Y ante esto, el 18 de julio tuvo una concepción nueva, encarnada por su Ministerio de Educación Nacional y su Dirección General de Bellas Artes: ésta fue la de crear una obra nacional de museología.

[...] Quien dude del contenido cultural que encierra el 18 de julio español, que tienda la mirada sobre algunas de estas actividades. España luchó para salvarse íntegramente. $Y$ en esta salvación estaban implícitos los tesoros de su arte y su historia. De ahí, que, lograda la Victoria, dispensara a la obra museal la atención que anotada queda. Ella, patrióticamente vista, es el cumplimiento de un compromiso contraído con uno de los valores más altos de nuestra vida como pueblo y como unidad de cultura (Barberán, 1945b: 21). 


\section{Notas}

1 Ver también: V.G.A. Reseña al libro: Menéndez Pidal, Ramón (1935), «Introducción a la España romana» (volumen Il de Historia de España, Espasa Calpe, Madrid), Revista de Estudios Políticos, n. ${ }^{\circ}$, enero 1941), pp. 128-131; Ballesteros, 1937.

2 Un esquema de la normalización del término, que no es asunto de estas páginas, puede verse en Filosofía en Español. En: <http://www.filosofia.org/ ave/002/b033.htm> (fecha de consulta: 12-06-2021).

3 En su editorial de presentación, de Federico Rahola, director de la publicación, se decía: «muerto ya definitivamente para las metrópolis el costoso empeño del dominio territorial [...] subsiste en cambio la afinidad de raza, la comunidad de ideas y la identidad de costumbres e idioma. No hay lazos que aventajen a estos para impulsar y sostener una gran corriente mercantil». Rahola, Federico (1901), «Nuestros propósitos», Mercurio. Revista comercial Hispano-Americana, 3 de diciembre, p. 1.

4 Como se recoge en la Gaceta de Madrid, 16 de junio de 1918.

5 La Conquista del Estado (1939), p. 5.

6 Ibidem, pp. 50-41.

7 El Sol, 12 de octubre de 1932. La retórica, en todo caso, no experimentó cambios; por ejemplo, el alcalde de Madrid en el acto central de las celebraciones en la capital dijo, refiriéndose a la lengua: «vinculará estrechamente cada día con más intensidad las relaciones fraternas y amorosas de España con sus hijos, los pueblos americanos». El Sol, 13 de octubre de 1932.

8 En su primer viaje a la Sociedad de Naciones, el ministro de Estado, Lerroux, no hizo mucho más que reiterar los tópicos tradicionales: «con la pérdida de las colonias careció de toda razón de ser toda preocupación territorial fuera del solar patrio, se reflejó mi espíritu en aquel ideal que se halla naturalmente constituido por la comunidad que forman [...] los países que hablan nuestro idioma». La Voz, 18 de mayo de 1931.

9 Ley de 2 de noviembre de 1940 por la que se crea el Consejo de la Hispanidad.

10 Tal y como se pone de manifiesto en numerosas publicaciones de los años cuarenta, como el emblemático texto de Arrarás y Sáez de Tejada, 1939.

11 Ver también Cabrera y Pérez, 2014. Un ejemplo lo encontramos en el artículo de Urrutia, Federico (1939), «La liturgia nazi», Vértice, n. 20 , abril, s.p.

12 Ideal, 18 de febrero de 1943.

13 «Actualidad gráfica», ABC (Madrid), 20 de mayo de 1948, p 5.

14 "Conmemoración histórica de la grandeza de España", $A B C$ (Sevilla), 3 de enero de 1939, p. 17.

15 «Relieves de Acción Católica. En vísperas de la Coronación», ABC (Madrid), 11 de julio de 1928, p. 4.

16 «La nueva España», $A B C$ (Sevilla), 18 de julio de 1941, p. 4.

17 «España conmemora, al mismo tiempo que en Perú, el Centenario de la muerte de Pizarro», $A B C$ (Madrid), 27 de junio de 1941, p.1; «En el Cuarto Centenario de la muerte de Pizarro", $A B C$ (Madrid), 21 de junio de 1941, p.3.

18 ABC (Madrid), 19 de enero de 1944, p. 7.

19 Cossío, 1940; Ibid., 2 de noviembre de 1940, p. 6.

20 Ver Actas de la Real Sociedad Colombina Onubense. En: <https://dspace.unia.es/handle/10334/785/browse> (fecha de consulta:25-05-/2021); «Proyectos de obras en los lugares colombinos", $A B C$ (Madrid), 4 de enero de 1952, p. 24.

21 «El cuatrocientos cincuenta aniversario de la salida de las naves descubridoras», ABC (Madrid), 6 de agosto de 1942, p.1.

22 Ibid., p.1.

23 «El Caudillo, la Hispanidad, el Pilar», Letras, n. 4, Extraordinario, 1940, p. 295.

24 Ibid., pp. 292-293.

25 Ibid., p. 295.

26 «El Pilar y la raza. España entera exaltó ayer con entusiasmo la Fiesta de la Hispanidad», ABC (Sevilla), 13 de octubre de 1940, p. 3.

27 "La fiesta del Pilar y de la Hispanidad», ABC (Madrid), 13 de octubre de 1939, pp. 7-10.

28 «El Pilar y la raza. España entera exaltó ayer con entusiasmo la fiesta de la hispanidad», ABC (Sevilla), 13 de octubre de 1940, pp. 3-4.

29 Ver Decreto 19 de abril 1941, BOE, 1 de mayo de 1941, nº 121.

30 "Solemne inauguración del Museo de América», ABC (Madrid), 14 de julio de 1944, p.11.

31 Ibid., p.11.

32 Ibid., p.11.

33 Ver también Barberán, 1945b.

34 Ver también <https://www.culturaydeporte.gob.es/museodeamerica/el-museo/historia/una-joya-arquitect-nica.html> (fecha de consulta: 25-05-2021).

35 (1951), «Las basílicas de Aránzazu y de la Merced», Sesiones de crítica de arquitectura, Revista Nacional de Arquitectura, n. 114, junio, pp. 30-43; (1939); Equipo redactor (1949), «Concurso de ideas para la construcción de una basílica hispano-americana a Nuestra Señora de la Merced en la prolongación de la Castellana: Primer premio", Revista Nacional de Arquitectura, n. 9 92, agosto, pp. 349-352. 


\section{Bibliografía}

ARANGUREN, José Luis (1937), «El arte de la España nueva», Vértice, n. ${ }^{\circ}$, septiembre, s. p.

ARRARÁS IRIBARREN, Joaquín y SÁEZ DE TEJADA, Carlos (1939), Historia de la Cruzada Española, Ediciones Españolas S. A., Madrid.

BARBERÁN, Cecilio (1944), «El poder creador del genio hispano», Abc (Madrid), 1 de octubre, p. 19.

BARBERÁN, Cecilio (1945a), «El Estado ante el patrimonio artístico nacional. La misión cultural de nuestro arte. La obra de las provincias», Abc (Sevilla), 2 de enero, p. 21.

BARBERÁN, Cecilio (1945b), «La exaltación de España a través de sus museos», Abc (Madrid), 18 de julio, p. 21.

CABRERA GARCÍA, M. ${ }^{a}$ Isabel (1998), Tradición y vanguardia en el pensamiento artístico español (1939-1959), Editorial Universidad de Granada, Granada.

CABRERA GARCÍA, M. ${ }^{a}$ Isabel (2012), «El pasado como condición: discurso artístico e identidad nacional durante el primer franquismo», en GARCÍA CUETOS, M. ${ }^{a}$ Pilar, ALMARCHA NÚÑEZ-HERRADOR, Esther y HERNÁNDEZ MARTíNEZ, Ascensión (coords.), Historia, restauración y reconstrucción monumental en la posguerra española, Abada editores, Madrid, pp. 41-64.

CABRERA GARCÍA, M. ${ }^{a}$ Isabel y PÉREZ ZALDUONDO, Gemma (2004), «La unidad: concepto referencial para las artes y la música en el primer franquismo", Cuadernos de Arte de la Universidad de Granada, n. ${ }^{\circ}$ 35, pp. 179-192.

CABRERA GARCÍA, M. ${ }^{a}$ Isabel y PÉREZ ZALDUONDO, Gemma (2004), (2014), «Voices, Strategies and Practices of Propaganda: Music and Artistic Culture at the Service of the State during Francoism», en SALA, Massimiliano (ed.), Music and Propaganda in the Short Twentieth Century, Turnhout, Brepols, pp. 207-224.

CASTRO, Cristóbal de (1945), «España y América. La nueva sensibilidad», Abc (Madrid), 2 de enero, p. 19.

Cossío, Francisco de (1940), "Los frescos de la Rábida», Abc (Madrid), 7 de noviembre, p. 3.

FONTENEBRO, Agustín (1944), «El Consejo de la Hispanidad restaura el Monasterio de la Rábida», Abc (Madrid), 13 de junio, p. 9.

GARCÍA CUETOS, M. ${ }^{a}$ Pilar; ALMARCHA, Esther y HERNÁNDEZ MARTíNEZ, Ascensión (coords.) (2012), Historia, restauración y reconstrucción monumental en la posguerra española, Abada editores, Madrid.

GARRIDO ATIENZA, Miguel (1998), Las fiestas de la Toma (1891), Editorial Universidad de Granada, Granada.

GIMÉNEZ CABALLERO, Ernesto (1935), Arte y Estado, Gráfica Universal, Madrid.

GIMÉNEZ CABALLERO, Ernesto (1979), Memorias de un dictador, Planeta, Barcelona.

GÓMEZ APARICIO, Pedro (1940), «El símbolo de los dos Belchites», Reconstrucción, n. 1, abril, pp. 6-10.

GRACIANI GARCÍA, Amparo (2013), «Presencia, valores, visiones y representaciones del hispanismo latinoamericano en la Exposición lberoamericana de Sevilla de 1929", Iberoamericana, año 13, n. ${ }^{\circ}$ 50, junio, pp. 133-146.

HERNÁNDEZ MARTíNEZ, Ascensión (2008), «La restauración de monumentos en Aragón (1936-1958)», en CASAR PINAZO, José Ignacio y ESTEBAN CHAPAPRÍA, Julián (eds.), Bajo el signo de la victoria. La conservación del patrimonio durante el primer franquismo (19361958), Pentagraf Editorial, Valencia, pp. 153-199.

HERNÁNDEZ MARTíNEZ, Ascensión (2012), «Algunas reflexiones en torno a la restauración monumental», en GARCÍA CUETOS, M. Pilar, ALMARCHA NÚÑEZ-HERRADOR, Esther y HERNÁNDEZ MARTÍNEZ, Ascensión (coords.), Historia, restauración y reconstrucción monumental en la posguerra española, Abada editores, Madrid, pp. 97-132.

LAíN ENTRALGO, Pedro (1937), «Meditación apasionada sobre el estilo de la Falange», Jerarquía. Revista Negra de Falange, s. n., octubre, pp. 164-169.

LEDESMA RAMOS, Ramiro (1931), «España, potencia de Imperio», La Conquista del Estado, n. 8, 2 de mayo.

LEDESMA RAMOS, Ramiro (1939), Discurso a las juventudes de España, ediciones FE, Madrid.

MARCILHACY, David (2014), "La Hispanidad bajo el franquismo, El americanismo al servicio de un proyecto nacionalista», en MICHONNEAU, Stéphane y NÚÑEZ SEIXAS, Xosé, M., Imaginarios y representaciones de España durante el franquismo, Casa de Velázquez, Madrid, pp. 73-102. 
MARTÍNEZ MONEDERO, Miguel (2008), «La confianza de un método: las restauraciones arquitectónicas de Luis Menéndez-Pidal», en CASAR PINAZO, José Ignacio y ESTEBAN CHAPAPRÍA, Julián (eds.), Bajo el signo de la victoria. La conservación del patrimonio durante el primer franquismo (1936-1958), Pentagraf Editorial, Valencia, pp. 266-272.

MENÉNDEZ PIDAL, Ramón (1935), «Introducción a la España romana», volumen 2 de Historia de España, Espasa-Calpe S. A., Madrid.

MOGOLLÓN CANO-CORTÉS, Pilar (2012), «La restauración y la transformación monumental en la posguerra. Indicadores y criterios de la eliminación de los revocos en las intervenciones extremeñas a través de las memorias de restauración», en GARCÍA CUETOS, M. ${ }^{a}$ Pilar, ALMARCHA NÚÑEZ-HERRADOR, Esther y HERNÁNDEZ MARTíNEZ, Ascensión (coords.), Historia, restauración y reconstrucción monumental en la posguerra española, Abada editores, Madrid, pp. 249-274.

MOYA BLANCO, Luis y MARTíNEZ FEDUCHI, Luis (1943), «Proyecto de edificio destinado a Museo de América», Revista Nacional de Arquitectura, n. ${ }^{\circ}$ 24, diciembre, pp. 411-416.

MURCIANO (1894), «La madre y las hijas», Unión Ibero Americana, 4 de agosto, p. 425.

PRIETO MORENO, Francisco, (1941), «Proyecto de reforma del acceso interior de la Cripta de los Reyes Católicos en la Capilla Real de Granada», Revista Nacional de Arquitectura, año I, n. ${ }^{\circ}$ 1, pp. 47-50.

PRIMO DE RIVERA, José Antonio (1970), Obras, Delegación Nacional de la Sección Femenina del Movimiento, Madrid.

REDONDO, Onésimo (1954), Obras completas, Publicaciones españolas, Madrid.

ROMERO GALLARDO, Aroa (2010), La restauración arquitectónica en el periodo franquista: la figura de Francisco Prieto Moreno y Pardo, Tesis Doctoral, Universidad de Granada.

SAZ CAMPOS, Ismael (2003), España contra España. Los nacionalismos franquistas, Marcial Pons, Madrid.

SEPÚLVEDA, Isidro (2013), «América en el nacionalismo español. El hispanoamericanismo», en MORALES MOYA, Antonio, FUSI AIZPURÚA, Juan Pablo y BLAS GUERRERO, Andrés de (dirs.), Historia de la nación y del nacionalismo español, Galaxia Gutenberg y Círculo de Lectores, Barcelona, pp. 1031-1047.

TOVAR, Antonio (1941), El Imperio de España, Ediciones Afrodisio Aguado, Madrid.

UNAMUNO, Miguel de (1910), «Sobre la argentinidad», La Nación, 11 de marzo. Recogido en UNAMUNO, Miguel (1960), Obras Completas, edición de Manuel García Blanco, Afrodisio Aguado, Madrid; IV, p. 810.

W. AA. (1939), La Conquista del Estado. Antología y prólogo de Juan Aparicio, Ediciones FE, Madrid.

VÁZQUEZ DE PARGA, M. ${ }^{a}$ Luisa (1969), «Museo de América», Reales Sitios, n. ${ }^{\circ}$ 6, pp. 105-112.

VICENTE (1944), «Unidad política y unidad religiosa en las tierras hispanas», Abc (Madrid), 4 de enero, p. 7. 